\title{
Status of Indian Mangroves
}

\author{
Ragavan $\mathbf{P}^{1^{*}}$ and Mandal $\mathbf{R N}^{2}$ \\ ${ }^{1}$ CSIR-National Botanical Research Institute, India \\ ${ }^{2}$ Regional Research Centre, ICAR-Central Institute of Freshwater Aquaculture, India
}

Submission: March 17, 2018; Published: May 31, 2018

Corresponding author: Ragavan P, SERB-National Post Doctoral Research Fellow, CSIR-National Botanical Research Institute, Lucknow, India, Email: van.ragavan@gmail.com

\section{Mini Review}

Despite the significant ecological and economical services, mangroves have witnessed an annual loss between 0.16 and $0.39 \%$, globally, due to rapid coastal development [1]. In south Asia (also known as Indian Subcontinent), mangrove forests have been lost at an average rate of $0.18 \%$ per year [2]. In India mangroves are spread over an area of $4921 \mathrm{~km}^{2}$, which representing $3.3 \%$ of the global mangrove vegetation [3]. In contrast to global trend, in India mangrove extent has increased in last decade. The estimates of Forest Survey of India show a net increase of $875 \mathrm{~km}^{2}$ during 1987-2017 when the mean annual change in mangrove extent was $30.21 \pm 81.72 \mathrm{~km}^{2}$; the extent of increase was $112 \mathrm{~km}^{2}$ between 2013 and 2015 and $181 \mathrm{~km}^{2}$ between 2015 to 2017 [3].

However, the global mangroves, as well as in India, have witnessed the implicit species loss despite mangrove expansion in many regions $[1,4,5]$. This calls for the evaluation of our understanding on mangrove dynamics and effectiveness of existing conservation methods and a refinement in them for better management of mangroves. Considering these facts in this text status of Indian mangroves have been discussed.

Mangrove forests in India are found along the coastline of 9 States and 4 Union Territories and it is the third richest country in the world in terms of mangrove species diversity with 46 true mangrove species belonging to 14 families and 22 genera [6]. However, the species diversity of Indian mangroves is under constant flux due to both natural (e.g. erosion, aggradations) and anthropogenic forces, possibly leading to changes in floristic composition and local extinction of some species. For instance, certain mangrove species viz., Heritiera littoralis, Xylocarpus granatum, Bruguiera cylindrica, Lumnitzera racemosa, Sonneratia caseolaris and Cynometra iripa are on the verge of extinction in the west coast $[7,8]$.

In east coast, the extent of Heritiera fomes, is estimated to have declined by $76 \%$ since 1959 and about $70 \%$ of the remaining $H$. fomes trees were affected by the 'top dying' disease [9]. Further, the populations of Nypa fruticans, and Xylocarpus molluccensis also underwent dramatic declines in Indian Sundarban [10].
Selvam [11] did not observe Xylocarpus granatum, Sonneratia apetala, Kandelia candel and Bruguiera gymnorhiza in Pichavaram mangroves, which were two decades earlier, from the region. About $52 \%$ of mangrove species in India have restricted distribution [6] and 9 species are of conservation significance at global level - Sonneratia griffithii and Heritiera fomes are 'critically endangered; Excoecaria indica and Aglaia cucullata are 'data deficient'; Aegialitis rotundifolia, Brownlowia tersa, Ceriops decandra, Phoenix paludosa and Sonneratia ovata are 'near threatened' [12]. In addition, mangrove floristics of mainland India not explored sufficiently in recent times.

Thus, species identity and distribution remains elusive in mangroves of mainland India. For instance, identity and distribution of Sonneratia griffithii in Sundarban and Odisha, Acanthus ebracteatus in Kerala and Odisha, Avicennia Alba in Kerala and Rhizophora stylosa in Odisha are not clear. Further, certain species like Aglaia cucullata, Bruguiera sexangula etc., are not found in the field more than decade. So the extensive floristics studies are precise to provide the correct identity and distribution of mangroves in East and west of India. Furthermore, efforts would be taken to increase the population of species under the risk of extinction or of low abundance.

Information of forest structure is the primary database that provides insight into the specific feature of each mangrove ecosystem. Mangrove stands exhibit wide regional and local variation in their structural characteristics as it is controlled by local site factors including topography, soil properties, and tide fluctuations $[13,14]$ than the climatic factors like rainfall and temperature, which controls the worldwide distribution of mangroves.

Hence, understanding local level forest structure is highly essential for their management. But in Indian context, studies on mangrove forest structure are very limited. Forest structural studies on Indian mangrove forests at Pichavaram and Muthupet [15-17], in Andaman Islands [18-23], in Odisha [24,25], in Andhra Pradesh [26-29], in Kerala [30-35], in Gujarat [36] and in Sundarbans [37-44] are noteworthy. Complexity index (Ic) and 
Important value index (Iv) are the structural indices often used to express existences of stress in the forest stand and importance of a tree species within a stand of mixed species respectively. Based on the available literature, it is event that except ANI, all other mangrove habitat in India has low Ic value and Avicennia marina constitutes the important tree species, whereas ANI exhibit high Ic value and Rhizophora species constitutes the important tree species. The low IC value indicating the low structural development and prevalence of disturbances in these mangrove stands.

Further abundance of Avicennia species indicates the prevalence of high saline condition in Indian mangrove habitat. Thus, despite the high species richness, species of low saline tolerant have restricted distribution. Abundances may decline long before the species richness does and so the species of low abundance should be given high conservation priority. Furthermore, mono-specific stands may have low thresholds for perturbations and be thus more vulnerable to environmental changes e.g. attack by diseases, drought, sedimentation, and flooding, among the stresses.

In recent times it has been understood that mangrove associated fauna play such a significant role to shape the mangrove forest structure and the functioning of the ecosystem [45-49]. Sediments, root structures and large woody debris are the three main substrata that fauna are able to exploit in mangroves $[45,50$ 53]. The faunal communities in mangroves chiefly consists of terrestrial (insects, birds, mammals and reptiles), aquatic (fish, crustaceans, molluscs and echinoderms) and benthic animals (polychaetes, brachyuran crabs, wood-boring animals, mud burrowing bivalves, gobiid fish, gastropods and some sessile bivalves, such as oysters, Modiolus spp. and barnacle crustaceans [54]. However, faunal assemblages of mangroves are significantly less studied and documented than the forests they inhabit.

Mangrove forest ecosystems in India support diverse groups of fauna comprising of 3091 species. This is perhaps the largest biodiversity record in world mangrove ecosystems [55]. Invertebrates are greater in number of species than vertebrates. The faunal species so far recorded were highest (2061) in the mangroves of the east coast, followed by 922 species in Andaman and Nicobar Islands and 727 species on the west coast. In recent times faunal diversity in different sites of Indian mangroves has been studied [56-62]. However, the knowledge on faunal assemblage in Indian mangroves is far from complete and it significances in shaping the forest structure and ecosystem functioning is not determined due to lack of consistent in quantitative data.

The population structure and distance over which gene flow occurs can inform management decisions regarding conservation and management of threatened ecosystems [63]. Since mangroves are at elevated risk understanding of genetic status and the degree of divergence among populations is a necessary for successfully preventing their extinction $[64,65]$. It was previously assumed that mangroves are genetically undifferentiated throughout its range due to long-distance oceanic dispersal of these propagules $[66,67]$.

However, experimental studies and recent molecular studies showed that strong genetic differentiation between populations of many mangrove species - Ceriops tagal and C. decandra [68], Lumnitzera racemosa [69,70], L. littorea [71], Rhizophora apiculata [72], Sonneratia caseolaris [73] and S. alba [74]. Except few regional specific studies [75-82], population structure of Indian mangroves has not been studied much. Patterns of genetic affinity and differentiation are generally explained by the presence of barriers in the landscape matrix, which may delay or hamper dispersal, and by testing the isolation-by-distance (IBD) model. Recent studies indicate the role of ocean currents, geomorphology, and hydrology of the estuary and water surface currents in shaping the population structure of mangrove species [83-86]. Furthermore, recent studies shown the low genetic diversity in the wide spread mangroves species of the world [87]. So understanding of regional specific population structure is desired for better understanding of current distribution pattern of mangrove species and conservation measures.

Biodiversity and ecosystem functioning of mangroves is determined by species composition and forest structure $[88,89]$. Since species diversity and distribution and forest structure of mangroves are variable in different spatial scales (i.e., global, regional, estuarine and intertidal), the ecological and socioeconomic benefits offered by mangroves are also variable between the region. So without site specific knowledge, it is imprecise to quantify the economic value of mangroves on broad scale at global level. In the last three decade various efforts have been taken to restore the degraded mangroves. However, many efforts have been documented to result in big failures in achieving the desired level of mangrove restoration due to poor species selection. In India, most of the mangrove restoration programmes were intended only to increase the area coverage and most afforestation efforts have been carried out with Avicennia species, with low or high survival rates.

On the whole in India mangrove cover has witnessed increasing trend and the number of mangrove taxa has also increased slightly on documentation since the mid-1980s, but their populations have not been tracked along the same trajectory. In the past, the conservation programmers for mangroves have largely been conducted with the lack of comprehensive speciesspecific information and often aimed to increase the area. In terms of mangrove conservation, only mangrove areas were rehabilitated, wherein ecological and economical services could not be fully restored. Since mangroves are present in land-sea transition zone, their natural extension is limited by urban development in landward side and sea level rise in seaward side.

The primary threats to all mangrove species are habitat destruction and removal of mangrove areas for conversion to 
aquaculture, agriculture, urban and coastal development, and overexploitation. Further, reduction in freshwater, nutrient enrichment through sewage discharge and sea level rise also threatened the mangrove species particularly low saline tolerant species. It is also pertinent to rejuvenate the species under significant threat (e.g. Sonneratia griffithii, Brownlowia tersa), especially those requiring stringent environmental conditions, like low salinity to grow (e.g. Heritiera fomes, Nypa fruticans etc,). Considering the low species richness and low genetic diversity it is imperative to assess the site specific information of mangroves to prevent it extinction. The contemporary mangrove conservation regime also advocates "early detection and preemptive rehabilitation", for successful management. And to achieve this, location-specific and species-specific information on the mangrove stands are the prerequisites [90], without which world without mangroves [91] will be a distinct possibility in the $22^{\text {nd }}$ century.

\section{References}

1. Hamilton SE, Casey D (2016) Creation of a high spatio-temporal resolution global database of continuous mangrove forest covers for the $21^{\text {st }}$ century (CGMFC-21). Global Ecology and Biogeography 25(6): 729-738.

2. Richards DR, Friess DA (2016) Rates and drivers of mangrove deforestation in Southeast Asia, 2000-2012. Proceedings of the National Academy of Sciences of the United States of America 113(2): 344-349.

3. FSI (2017) India state of Forest Report, Forest survey of India, Dehradun, India, pp. 55-61.

4. Giri C, Zhu Z, Tieszen LL, Singh A, Gillette S, et al. (2008) Mangrove forest distributions and dynamics (1975-2005) of the tsunami-affected region of Asia. Journal of Biogeography 35(3): 519-528.

5. Giri C, Long J, Abbas S, Murali RM, Qamer FM, et al. (2015) Distribution and dynamics of mangrove forests of South Asia. J Environ Manag 148:101-111.

6. Ragavan P, Saxena A, Jayaraj RSC, Mohan PM, Ravichandran K, et al. (2016) A review of the mangrove floristics of India. Taiwania 61(3): 224-242.

7. Chavan NS (2013) New area record of some mangrove species and associates from the coast of Maharashtra, India. Seshaiyana 21: 2-3.

8. Upadhyay VP, Ranjan R, Singh JS (2002) Human mangrove conflicts: The way out. Current Science 83(11): 1328-1336.

9. Chowdhury MQ, Schmitz N, Verheyden A, Sass-Klaassen U, Koedam N, et al. (2008) Nature and periodicity of growth rings in two Bangladeshi mangrove species. IAWA Journal 29(3): 265-276.

10. Iftekhar MS, Saenger P (2008) Vegetation dynamics in the Bangladesh Sundarbans mangroves: a review of forest inventories. Wetlands Ecology and Management 16: 291-312.

11. Selvam V (2003) Environmental classification of mangrove wetlands of India. Current Science 84: 757-764.

12. Polidoro BA, Carpenter KE, Collins L, Duke NC, et al. (2010) The loss of species: mangrove extinction risk and geographic areas of global concern. PLoS One 5(4): e10095.

13. Smith TJ (1992) Forest structure. In: Robertson AI, Alongi DM (Eds.), Tropical mangrove ecosystems. American Geophysical Union, Washington DC, USA, pp. 101-136.
14. Kauffman JB, Cole TG (2010) Micronesian Mangrove Forest Structure and Tree Responses to a Severe Typhoon. Wetlands 30: 1077-1084.

15. Muniyandi K (1986) Studies on Mangroves of Pichavaram (South East Coast of India). Ph. D. Thesis, Parangipettai, India.

16. Kathiresan K, Ramesh M, Venkatesan V (1994) Forest structure and prawn seeds in Pichavaram mangroves. Environment and Ecology 12: 465-468.

17. Kathiresan K, Saravanakumar K, Anburaj R, Gomathi V (2016) A simple method for assessing mangrove forest based on young plants and sesarmid crab holes. Regional Studies in Marine Science 7: 204-210.

18. Dagar JC (1987) Mangrove vegetation, its structure, ecology, management and importance with special reference to Andaman and Nicobar Islands. In: Proceedings of Symposium on Management of Coastal Ecosystems and Oceanic Resources of the Andamans. $17^{\text {th }}-18^{\text {th }}$ July, 1987, Andaman Science Association (CARI), Port Blair, India, pp. 8-23.

19. Singh VP, Mall LP, Garge A, Pathak SM (1990) Human impact assessment on mangrove forests of Andaman Islands. Indian Forester 116(2): 131139.

20. Mall LP, Singh VP, Garge A (1991) Study of biomass, litter fall, litter decomposition and soil respiration in monogeneric mangrove and mixed mangrove forests of Andaman Islands. Tropical Ecology 32: 144-152.

21. Singh VP, Odaki K (2004) Mangrove Ecosystems: Structure and Function. Scientific Publishers, Jodhpur, India.

22. Ragavan P, Saxena A, Mohan PM, Ravichandran K, Jayaraj RSC, et al. (2015) Diversity, distribution and vegetative structure of mangroves of the Andaman and Nicobar Islands, India. Journal of Coastal Conservation 19(4): 417-443.

23. Kiruba-Sankar R, Krishnan P, Dam-Roy S, Raymond Jani Angel J, Lohith Kumar K, et al. (2017) Structural complexity and tree species composition of mangrove forests of the Andaman Islands, India. Journal of Coastal Conservation.

24. Upadhyay VP, Mishra PK (2008) Population status of mangrove species in estuarine regions of Orissa Coast, India. Tropical Ecology 49: 183188.

25. Upadhyay VP, Mishra PK (2010) Phenology of mangroves tree species on Orissa Coast, India. Tropical Ecology 51: 289-295.

26. Azariah J, Azariah H, Gunasekaran S, Selvam V (1992) Structure and species distribution in Coringa mangrove forest, Godavari delta, Andhra Pradesh, India. Hydrobiologia 247: 11-16.

27. Venkanna P, Narasimha Rao GM (1993) Distribution pattern of the Mangroves in the Krishna estuary. Indian J For 16: 48-53.

28. Satyanarayana B, Raman AV, Dehairs F, Kalavati C, Chandramohan P, et al. (2002) Mangrove floristics and zonation pattern of Coringa, Kakinada Bay, East coast of India. Wetl Ecol Manag 10(1): 25-37.

29. Satyanarayana B, Raman AV, Mohd-Lokman H, Dehairs F, Sharma VS, et al. (2009) Multivariate methods distinguishing mangrove community structure of Coringa in the Godavari Delta, east coast of India. Aquatic Ecosyst Health 12: 401-408.

30. Nameer PO, Mohan Kumar B, Minood CR (1992) Floristics, zonation and above ground biomass production in the mangroves of Puduvyppu, Kerala. Ind J For 15: 317-325.

31. Suresh Kumar S, Mohan Kumar B (1997) Floristics, biomass production and edaphic attributes of the mangrove forests of Puduvyppu, Kerala. Ind J For 20: 136-143.

32. Rahees N, Kiran M, Vishal V (2014) Phytosociological analysis of mangrove forest at Kadalundi-Vallikkunnu community reserve, Kerala. Inter J Sci Tech 3(6): 2154-2159. 
33. Vijayan V, Rahees N, Vidyasagaran K (2015) Plant diversity and structural dynamics of mangroves in the southwest coast of Kerala, India. Appl Ecol Env Res 13(4): 1055-1067.

34. Rani V, Sreelekshmi S, Asha CV, Bijoy Nandan S (2016) Forest structure and community composition of Cochin mangroves, south-west coast of India. Natl Acad Sci 88(1): 111-119.

35. George G, Krishnan P, Mini KG, Salim SS, Ragavan P, et al. (2018) Structure and regeneration status of mangrove patches along the estuarine and coastal stretches of Kerala, India. Journal of Forestry Research.

36. Sawale A, Thivakaran GA (2013) Structural Characteristics of Mangrove Forest of Kachchh, Gujarat. Journal of Marine Biological Association of India 55: 5-11.

37. Mukherjee BB, Mukherjee J (1970) Mangroves of Sunderbans, India. Phytomorphology 28: 192-217.

38. Matilal S, Mukherjee BB, Chatterjee N, Gupta MD (1986) Studies on soil \& vegetation of mangrove forests of Sundarbans. Indian Journal of Marine Sciences 15: 181-184.

39. Chaudhuri AB, Chakrabarti K (1989) Sunderban Mangrove -Ecology and Wild Life. Jugal Kishore \& Company, Dehradun, India.

40. Saha S, Choudhury A (1995) Vegetation analysis of restored and natural mangrove forests in Sagar Island, Sundarbans, east coast of India. Indian Journal of Marine Sciences 24: 133-136.

41. Joshi HG, Ghose M (2003) Forest structure and species distribution along soil salinity and $\mathrm{pH}$ gradient in mangrove swamps of the Sundarbans. Tropical Ecology 44(2): 197-206.

42. Joshi HG, Ghose M (2014) Community structure, species diversity, and aboveground biomass of the Sundarbans mangrove swamps. Tropical Ecology 55: 283-303.

43. Naskar KR, Mandal RN (1999) Ecology and biodiversity of Indian mangroves. Vols. I \& II. Daya Publishing House, New Delhi, India.

44. Mandal RN, Naskar KR (2008) Diversity and classification of Indian mangroves: a review. Tropical Ecology 49(2): 131-146.

45. Kristensen E (2007) Mangrove crabs as ecosystem engineers, with emphasis on sediment processes. J Sea Res 59(1-2): 30-43.

46. Lee SY (2007) Mangrove macrobenthos: assemblages, services, and linkages. J Sea Res 59(1): 16-29.

47. Cannicci S, Burrows D, Fratini S, Smith TJ, Offenberg J, et al. (2008) Faunistic impact on vegetation structure and ecosystem function in mangrove forests: A review. Aquatic Botany 89: 186-200.

48. Kristensen E, Bouillon S, Dittmar T, Marchand C (2008) Organic carbon dynamicsin mangrove ecosystems: A review. Aquatic Botany 89(2): 201-219.

49. Nagelkerken I, Blaber SJM, Bouillon S, Green P, Haywood M, et al. (2008) The habitat function of mangroves for terrestrial and marine fauna: A review. Aquatic Botany 89(2): 155-185.

50. Ellison AM, Farnsworth EJ (1990) The ecology of Belizean mangroveroot fouling communities. I. Epibenthic fauna are barriers to isopod attack of red mangrove roots. Journal of Experimental Marine Biology and Ecology 142(1-2): 91-104.

51. Ellison AM, Farnsworth EJ, Twilley RR (1996) Facultative mutualism between red mangroves and root-fouling sponges in Belizean mangal. Ecology 77(8): 2431-2444.

52. Cragg SM, Hendy IW (2010) Mangrove forests of the Wakatobi National Park. In: Clifton J, Unsworth RKF, Smith DJ, (Eds.), Marine research and conservation in the coral triangle. Nova Science Publishers, Hauppauge, New York, USA.
53. Hendy IW, Eme J, Dabruzzi TF, Nembhard RV, Cragg SM, et al. (2013) Dartfish use teredinid tunnels in fallen mangrove wood as a low-tide refuge. Marine Ecology Progress Series 486: 237-245.

54. Kathiresan K, Veerappan N, Balasubramanian R (2015) Status of Fauna in Mangrove Ecosystems of India. In Marine Faunal Diversity in India pp. 485-497.

55. Kathiresan K (2000) Mangrove Atlas and Status of species in India. Report submitted to Ministry of Environment and Forest, Govt. of India, New Delhi, India, p. 235.

56. Gopikumar K, Sunil PK, Joseph JM, Hedge HT (2008) Biodiversity of mangrove forests of Cochin coast of Kerala. Institute of Wood Science and Technology, Bangalore, India, p. 13.

57. Khaleel KM (2008) Management strategies for the mangrove wetlands of North Malabar. Institute of Wood Science and Technology, Bangalore, India, p. 73.

58. Bhosale LJ (2008) Biodiversity of mangroves of Ratnagiri and Sindhudurg districts of Maharashtra. Institute of Wood Science and Technology, Bangalore, India, p. 10.

59. Remadevi OK, Latheef CA, Chatterjee D, Rajani K (2008) Nocturnal insect diversity in Coringa mangroves-analysis of occurrence and distribution. Institute of Wood Science and Technology, Bangalore, India, p. 35.

60. Latheef CA, Remadevi OM, Chatterjee D (2008) Propagule predation on Rhizophora mucro $\neg$ nata by a moth borer and its impact on the germination of the propagule. Institute of Wood Science and Technology, Bangalore, India, p. 30.

61. Rajavel AR, Natarajan R (2008) Species diversity of mosquitoes in relation to the larval habitats in mangroves of India. Institute of Wood Science and Technology, Bangalore, India, p. 29.

62. Santhakumaran LN (2008) Role of marine wood borers in mangrove environment - Is it biodeteriาoration or degradation? Institute of Wood Science and Technology, Bangalore, India, p. 27.

63. Homer LE (2009) Population structure and distance of gene flow in Avicennia marina (Forsk.) Vierh.(Avicenniaceae) on a local/regional scale in the Northern Rivers of New South Wales, Australia.

64. Zhang HY, Mao XG, Wang CS, Jing RL (2010) Over expression of a common wheat gene TaSnRK2.8 enhances tolerance to drought, salt and low temperature in Arabidopsis. PLoS One 5: e16041.

65. Zhao B, Yin ZF, Xu M, Wang QC (2012) AFLP analysis of genetic variation in wild populations of five Rhododendron species in Qinling Mountain in China. Biochemical Systematics and Ecology 45: 198-205.

66. Duke NC, Benzie JAH, Goodall JA, Ballment ER (1998) Genetic structure and evolution of species in the mangrove genus Avicennia (Avicenniaceae) in the Indo-West Pacific. Evolution 52(6): 1612-1626.

67. Maguire TL, Saenger P, Baverstock P, Henry R (2000) Microsatellite analysis of genetic structure in the mangrove species Avicennia marina (Forsk.) Vierh. (Avicenniaceae). Molecular Ecology 9(11): 1853-1862.

68. Huang Y, Tan F, Su G, Deng S, He H, et al. (2008) Population genetic structure of three tree species in the mangrove genus Ceriops (Rhizophoraceae) from the Indo West Pacific. Genetica 133(1): 47-56.

69. Su G, Huang Y, Tan F, Ni X, Tang T, et al. (2006) Genetic variation in Lumnitzera racemosa, a mangrove species from the Indo-West Pacific. Aquatic Botany 84: 341-346.

70. Li J, Yang Y, Chen Q, Fang L, He Z, et al. (2016) Pronounced genetic differentiation and recent secondary contact in the mangrove tree Lumnitzera racemosa revealed by population genomic analyses. Scientific Reports 6: 29486. 
71. Su G, Huang Y, Tan F, Ni X, Tang T, et al. (2007) Conservation genetics of Lumnitzera littorea (Combretaceae), an endangered mangrove, from the Indo-West Pacific. Marine Biology 150: 321-328.

72. Guo Z, Huang YJ, Chen Y, Duke NC, Zhong C, et al. (2016) Genetic discontinuities in a dominant mangrove Rhizophora apiculata (Rhizophoraceae) in the Indo-Malesian region. Journal of Biogeography 43(9): 1856-1868.

73. Yang Y, Duke NC, Peng F, Li J, Yang S, et al. (2016) Ancient Geographical Barriers Drive Differentiation among Sonneratia caseolaris Populations and Recent Divergence from S. lanceolata. Frontiers in Plant Science 7: 1618.

74. Yang Y, Li J, Yang S, Li X, Fang L, et al. (2017) Effects of pleistocene sealevel fluctuations on mangrove population dynamics: A lesson from Sonneratia alba. BMC Evol Biol 17: 22.

75. Parani M, Lakshmi M, Elango S, Ram N, Anuratha CS, et al. (1997) Molecular phylogeny of mangroves II. Intra and inter-specific variation in Avicennia revealed by RAPD and RFLP markers. Genome 40: 487 495.

76. Parani M, Rao CS, Mathan M, Anuratha CS, Kottaram K Narayanan, et al. (1997) Molecular phylogeny of mangroves III. Parentage analysis of Rhizophora hybrid using random amplified polymorphic DNA (RAPD) and restriction fragment length polymorphism (RFLP) markers. Aquatic Botany 58(2): 165-172.

77. Lakshmi M, Rajalakshmi S, Parani M, Anuratha CS, Parida A, et al (1997) Molecular phylogeny of mangroves I. Use of molecular markers in assessing the intra-specific gene variability in the mangrove species, Acanthus ilicifolius Linn. (Acanthaceae). Theor Appl Genet 94(8): 1121-1127.

78. Lakshmi M, Parani M, Ram N, Parida A (2000) Molecular phylogeny of mangroves VI. Intraspecific genetic variation in mangrove species Excoecaria agallocha L. (Euphorbiaceae). Genome 43(1): 110-115.

79. Jugale SB, Bhosale LJ, Kad TD, Nadaf AB (2009) Genetic diversity assessment inintra- and inter-populations of Xylocarpus granatum Koen.: a critically endangered and narrowly distributed species of Maharashtra. Current Science 97(5): 659-701.

80. Pawar UR, Baskaran J, Ajithkumar P, Panneerselvam R (2013) Genetic variation between Xylocarpus spp. (Meliaceae) as revealed by Random Amplified Polymorphic DNA (RAPD) markers. Emir J Food Agric 25(8): 597-604.
81. Saddhe AA, Jamdade RA, Kumar K (2016) Assessment of mangroves from Goa, west coast India using DNA barcode. Springer Plus 5(1): 1554.

82. Dasgupta N, Nandy P, Sengupta C, Das S (2017) Genetic variation in relation to adaptability of three mangrove species from the Indian Sundarbans assessed with RAPD and ISSR markers. Journal of Forestry Research.

83. Dodd RS, Afzal-Rafii Z, Kashani N, Budrick J (2002) Land barriers and open oceans: effects on gene diversity and population structure in Avicennia germinans L. (Avicenniaceae). Mol Ecol 11(8): 1327-1338.

84. Orsini L, Vanoverbeke J, Swillen I, Mergeay J, Meester L, et al. (2013) Drivers of population genetic differentiation in the wild: isolation by dispersal limitation, isolation by adaptation and isolation by colonization. Molecular Ecol 22(24): 5983-5999.

85. Wee AKS, Takayama K, Asakawa T, Thompson B, Sungkaew S, et al. (2014) Oceanic currents, not land masses, maintain the genetic structure of the mangrove Rhizophora mucronata Lam. (Rhizophoraceae) in Southeast Asia J Biogeogr 41(5): 954-964.

86. Cerón-Souza I, Gonzalez EG, Schwarzbach AE, Salas-Leiva DE, RiveraOcasio E, et al. (2015) Contrasting demographic history and gene flow patterns of two mangrove species on either side of the Central American Isthmus. Ecology and Evolution. 5(16): 3486-3499.

87. Guo Z, Li X, He Z (2018) Extremely low genetic diversity across mangrove taxa reflects past sea level changes and hints at poor future responses. Glob Change Biol 24(4): 1741-1748.

88. Soares MLG (2009) A conceptual model for the responses of mangrove forests to sea level rise. Journal of Coastal Research 56: 267-271.

89. Cavalcanti VE, Soares MLG, Estradat GCD, Chavest FO (2009) Evaluating mangrove conservation through the analysis of forest. Journal of Coastal Research 56: 390-394.

90. Lewis RR, Milbrandt EC, Brown B, Krauss KW, Rovai AS, et al. (2016) Stress in mangrove forests: early detection and pre-emptive rehabilitation are essential for future successful worldwide mangrove forest management. Mar Poll Bull 109(2): 764-771.

91. Duke NC, Meynecke JO, Dittmann S, Ellison AM, Anger K, et al. (2007). A world without Mangroves? Science 317: 41-43.

Your next submission with Juniper Publishers
will reach you the below assets
- Quality Editorial service
- Swift Peer Review
- Reprints availability
- E-prints Service
- Manuscript Podcast for convenient understanding
- Global attainment for your research
- Manuscript accessibility in different formats
( Pdf, E-pub, Full Text, Audio)
- Unceasing customer service
Track the below URL for one-step submission
https://juniperpublishers.com/online-submission.php

